\title{
Report of the Managing Director to the Board of Governors and to the Executive Board Pursuant to Article XVIII, Section 4(c)
}




\section{INTERNATIONAL MONETARY FUND}

\section{Report of the Managing Director to the Board of Governors and to the Executive Board Pursuant to Article XVIII, Section 4(c)}

Prepared by the Finance, Legal, and Strategy, Policy, and Review Departments Approved by Bernard Lauwers, Rhoda Weeks-Brown, and Ceyla Pazarbasioglu

June 30, 2021

1. This report is submitted pursuant to the provisions of the Articles of Agreement regarding a general allocation or cancellation of Special Drawing Rights (SDR) for the Twelfth Basic Period that begins on January 1, 2022. The Articles of Agreement provide for periodic consideration and decisions on SDR allocations or cancellations in the context of consecutive basic periods of normally five years of duration (Article XVIII, Section 2(a)). Pursuant to Article XVIII, Section 4(c)(i), the Managing Director must make a proposal to the Board of Governors no later than six months before the end of each basic period regarding a general allocation or cancellation in the next basic period. The Eleventh Basic Period for a general allocation or cancellation of SDRs began on January 1, 2017 and is scheduled to end on December 31, 2021. The Twelfth Basic Period will commence on January 1, 2022.

2. Under the Articles, in making any proposal for a general allocation or cancellation of SDRs, the Managing Director must be satisfied that the proposal, in her view: (i) is consistent with the objective of meeting the long-term global need to supplement existing reserve assets as described in Article XVIII, Section 1(a); and (ii) would have broad support among participants (Article XVIII, Section 4(b)). Executive Board concurrence is required under Article XVIII, Section 4(a) for the proposal. A decision of the Board of Governors approving such a proposal of the Managing Director requires an 85 percent majority of the total voting power of participants in the SDR Department (Article XVIII, Section 4(d)). If the Managing Director ascertains that there is no proposal consistent with Article XVIII, Section 1(a) that has broad support among participants, she must so report to the Board of Governors and to the Executive Board (Article XVIII, Section 4(c)).

3. The Board of Governors will soon receive a proposal for a general SDR allocation equivalent to about US $\$ 650$ billion during the current Eleventh Basic Period. In March 2021, I put forward initial considerations for an SDR allocation and initiated consultation with the membership. Executive Directors at an informal Executive Board meeting on March 23, 2021 conveyed broad support of Fund members for a general allocation. The International Monetary and Financial Committee (IMFC) at its April 8, 2021 meeting called for a comprehensive proposal on a new SDR general allocation of about US $\$ 650$ billion. At a meeting of the Executive Board on June 25, 2021, Directors expressed broad support for my detailed assessment of the case and proposed modalities for a general allocation of SDRs in an amount equivalent of about US $\$ 650$ billion (about SDR 453 billion) during the Eleventh Basic Period. I will shortly circulate to the Executive Board a report to the Board of 
Governors with the formal proposal. Upon the concurrence by the Executive Board, the report, including a proposed Board of Governors resolution, will be transmitted to the Board of Governors for its approval.

4. The proposed general allocation for the Eleventh Basic Period, once approved by the Board of Governors and implemented, would help address the long-term global need to supplement existing reserve assets. Against this background, I have concluded that there is no case at this point for an allocation of SDRs for the Twelfth Basic Period. Nonetheless, during the course of the Twelfth Basic Period, I would bring the issue of a general allocation or cancellation of SDRs before the Executive Board for further discussion, if and when appropriate, in accordance with Article XVIII, Section 4(c)(ii). The Board of Governors or the Executive Board may also request that I make proposals at any time. 